\title{
The Novelist as a Mirror of the Society: A Study of Biyi Bandele Thomas' The Man Who Came in From the Back of Beyond
}

\author{
B. N. Egede, Oseghale Francis \\ Ambrose Alli University, Ekpoma, Nigeria
}

\begin{abstract}
It is the duty of the novelist to both express and document the problems prevalent in his society and his dissatisfaction with these problems through his novel. In a novel that mirrors the ills in the society, the novelist takes care to properly, effectively, and convincingly document what he has seen in the society and sometimes proffers solutions to these problems. The novelist has a significant role to play through his novel. He can make the people to be aware of what is happening in the society, so that they can react to it. Many African novelists have, over the years, expressed their anger, dissatisfaction, and disillusionment over the social, economic, and political problems confronting post-independence African societies through their works. In post-independence Africa, a number of African novelists have their works characterized by pessimism, anger, failure in governance, and disillusionment of the people. Most African writers write to criticize these social, economic, and political ills ravaging the society. The plebeians need to be educated by the writers on their exploitation by the few elites who govern them. Hence, African novelists have come out fearlessly to respond to the various social, economic, and political vices that are being perpetrated by their leaders. It is against the backdrop of the foregoing that Bandele Thomas examines the hydra-headed problems of political thuggery, corruption, armed robbery, drug abuse, prostitution, unemployment, and insensitivity of the government to the plight of the masses in his novel The Man Who Came From the Back of Beyond.
\end{abstract}

Keywords: novelist, mirror society, disillusionment, looting, moral decay

\section{Introduction}

The role of the writer as the conscience of the society is to give a vivid pictorial view of the society as he sees it. It is therefore the duty of the writer as the unacknowledged legislator of mankind to mirror his society objectively for the people to see. Our contemporary day society is bedeviled by many vices. Its development stunted by the depredations of its ruling elite. A good number of people, the helm of affairs, in our society at the different level of governance are mainly concerned with the looting of the state treasury and are indifferent to whether the system survives or not. Most people in power are morally and spiritually corrupt. Besides, they are callous and insensitive as they do not see anything wrong in any system trying to pauperize and or subjugate the vast majority of the citizens constituting the system, because they want to increase their wealth by all means, fair or foul.

Prof. B. N. Egede, Ph.D., Professor, Faculty of Arts, Department of English, Ambrose Alli University, Ekpoma, Nigeria.

Oseghale Francis, Ph.D., Associate Professor, Faculty of Arts, Department of English, Ambrose Alli University, Ekpoma, Nigeria. 
One cannot estimate the harm, damage, and frustration that corruption and bad governance have done to our society. Our society indeed has been fatally hamstrung by corruption and bad governance. Its development has become stunted and its progress as a modern society greatly arrested and this makes life difficult for the citizens. Corruption and evil conduct in governance have compromised national development, contaminated collective morality and values, distorted national planning, corroded integrity and discipline, and destroyed the foundations of creativity, innovation, democratic structures, and values.

Furthermore, corruption and mis-governance lead to social and moral decadence, political thuggery, armed robbery, drug addiction, prostitution, unemployment, hooliganism, and insanity in the society. If the society is faced with these multifarious problems, it is the duty of the writer, as the mirror of the society, to point them out. He has a responsibility to point them out. This is what Biyi Bandele Thomas has done in the novel The Man Who Came in From the Back of Beyond. He channels his anger against a society that is corrupt, sick, and rotten one that requires urgent rescue from the hands of those destroying it. In The Man Who Came in From the Back of Beyond, on account of their misguided, ill-governance, Biyi Bandel Thomas performs the duty of a writer which is to salvage the society from these vices.

\section{Social Vices in The Man Who Came in From the Back of Beyond}

The novel entitled The Man Who Came in From the Back of Beyond by Biyi Bandele Thomas portrays the various ills in our society. The author vividly pictures the moral decay, family disintegration, drug abuse, extremism, and other social vices ravaging the entire social system. The author shows, through this novel, how sad and bitter he feels about these vices in the society. The novel is a realistic depiction of our society that is in shambles that calls for urgent attention in order to save it from total collapse.

The novel is centered around the main character called Bozo. Through this central character, the author shows and condemns our contemporary society with all its attendant vices. The author also portrays the helplessness, hopelessness, and the disillusionment in our society. He sees our society as a place where the citizens are uncomfortable as if they are in hell.

The novel begins with the description of the Literature and English teacher, Maude Beso, by Lakemfa, one of his students, Maude is portrayed as a man going through mental agony and moral anguish as a result of the multifarious problems he is encountering in the society. Lakemfa, his student, describes him in this way:

The very first time I saw him, I had the distinct but unfathomable impression that I was staring at a man on his way to the gallows. Maybe this unconscious ability of his to plant in one's mind the most morbid pictures had to do with his wiry, kwashiorkor-syndrome stature. He was a man of very small stature, standing like the cob of a corn, lean like a blind man's staff, and this was not mitigated in any way by the walnut-shaped infamy that went by the name of his head. (p. 1)

The pathetic description of the Literature and English teacher shows the picture of a man that is suffering and getting older than his true age. This is as a result of the degrading socio-political and economic problems confronting him and other members of the society. The author decides to expose these problems in this novel. The novelist as the conscience of the society needs to expose such problems in his work. The position of the author authenticates the view expressed by Olawele Awosika (1997). According to him, "The socio-political and economic problems confronting the African world today are so over-powerful that it would be surprising if the novelists did not show as much awareness of them as they have done" (p. 4).

One Sunday morning, Lakemfa decides to visit his teacher Maude. He meets him taking his breakfast. Lakemfa discovers his teacher is a vegetarian; Maude believes in eating to live and not living to eat. He is more 
concerned with taking care of the mind, spirit, and soul instead of the body which to him is just an envelope covering the mind, spirit, and soul. He believes that we should not pay undue attention to the pleasure of the flesh. According to him,

Is it really ourselves we are seeing in the mirror or something else? A vessel perhaps which we are only temporarily inhabiting? If it is so, should we not take a little more care, pay a little more attention to that innermost thing in what we call our body, the real self that really constitutes our consciousness? And what is this real self? It is the mind, the spirit, our only link to what is called soul. What one says is that we should not pay undue attention to pleasures of the flesh. You should not be a glutton. Rather you should feed mind with pure thoughts. (p. 10)

This view of Maude about the importance of the mind, spirit, and soul over the body confirms the view expressed by Plato. Plato conceives man, as made up of two substances: a spiritual substance that is the soul and a material substance that is the body. Plato believes that the soul is the most important part of man and man should be more concerned of taking care of it than the body. This is why Joseph I. Omoregbe (1989), expressing the view of Plato, said:

In fact the soul is the essential part of man. It just happens to be encased or imprisoned in a material body. The soul in the body is like a prisoner in a prison or a pilot in a ship. (p. 1)

Maude later tells Lakemfa a diachronic story of his life. According Maude, he never finished his secondary school education. He left school when he was 16 years old because his mother was sick of breast cancer and he does not know his father because his mother was a prostitute. According to Maude, his maternal grandfather was a bus conductor who later became a political thug for one of the political parties. He decides to become a political thug because he was paid 10 times more than what he receives as bus conductor. However, the political upheavals in the country lead to the almost complete annihilation of the entire family. Only Maude's mother survives when their house was set ablazed at night by a political enemy. According to Maude:

Her father a gullible man who, materially, could only think as far as the next meal, was hired as a thug by one of the political parties for ten times as much as he got daily as a bus conductor. And the job was simple, all a thug had to do was burn up or destroy property belonging to rival parties. And occasionally take a miserable life or two. There were swift reactions, of course. Instant retaliation. And one day as the ex-conductor and his family slept in their two-room shack at Ajegunle, someone covered by the silent night crept up surreptitiously and painted the shack with a tin of petrol. Then stepped back and lit a match. Only my mother survived the fire. The rest of her family? They died. (p. 12)

This inhuman action against Maude's maternal grandfather and his family by his political enemy shows that morality must be removed from politics. This is the view held by Niccolo Machiavelli. Machiavelli tells us that the essential thing in politics is to try to grab power by all means, fair or foul. Joseph I. Omoregbe (1989) also expressed this same view as Niccolo Machiavelli. Joseph I. Omoregbe believes that the ruler or seeker of political power must be very shrewd, prudent, practical, and swift. According to him:

He could be violent and brutal but he must do so in a shrewd and swift manner and succeed in achieving his aim. A Prince does not need to be a morally upright man, he does not need to be honest or to be humane. He does not need to be religious or compassionate. (p. 129)

All these views expressed by Niccolo Machiavelli and Joseph I. Omoregbe were vividly manifested by the politicians of the early sixties in Nigeria. So, the novelist uses the mayhem that befalls Maude's maternal grandfather to show the catastrophic nature of political vendetta in the 1960s in Nigeria. This type of mayhem, in the view of the novelist, should not be encouraged because it brings untold hardship and drastic setback to 
the entire society.

After the annihilation of Maude's mother's family by their political rival, she could not do any meaningful thing to earn a living. She therefore goes to Jos where she becomes a prostitute at of the tender age of 13. It was during her prostitution that Maude was born and Maude's mother later dies of breast cancer. This may be as a result of lack of care and prostitution. The agony Maude's mother goes through before her death is similar to what Wanja in Ngugi Wa Thiongo's (1977) Petals of Blood suffered in her encounter with unscrupulous men. Wanja is seduced at an early age by an irresponsible married man old enough to be her father. She finds herself pregnant like Maude's mother just as she is about to start higher education. So, she has to leave home and school instead of her to bear the taunts and maltreatment of her parents; later, she murders her baby and finds herself in the big city, to face more exploitation and sexual abuse from men. The exploitation and sexual abuse of Wanja by men old enough to be her father show how the politicians and the rich men in the society exploit and degrade young girls who are less privileged and financially handicapped. Hence, Eustance Palmer (1982) said of Wanja:

Seduced at an early age by an irresponsible married man old enough to be her father, she finds herself pregnant just as she is about to embark on higher education, and has to leave home and school rather than endure the taunts and cruelty of her parents. In desperation she murders her baby and is thrown in the city, on the mercies of even more unscrupulous men determined to exploit and degrade her. (p. 298)

Wanja is later thrown back into high-class prostitution through the intrigues and dubious activities of the new black imperialists who are ready to exploit and destroy young innocent girls like Wanja.

From the exploitation and destruction of Maude's mother and Wanja, both Biyi Bandele Thomas and Ngugi Wa Thiongo are telling us that our leaders and politicians are not ready to help, rehabilitate, and reintegrate the less privileged young girls in the society but rather, eager to exploit, degrade, and sexually destroy them. The authors believe that this is a heinous crime against humanity and our leaders should desist from it.

After the miserable death of Maude's mother, he takes to the streets to do menial jobs, like shoe shinning, newspaper vending, fast food vendor, etc. Hence, the author says of Maude: “...I variously worked as a shoe-shine boy, a newspaper vendor, a fast food-vendor, an ice-cream vendor, a garbage collector, and unskilled labourer at a building site, a bus conductor and even-a thief" (p. 14).

Maude takes to stealing and he finds that people are disillusioned like him over the manner the leaders handle the problems of the downtrodden in the society. Maude and his master rob in the train by stealing money from passengers' pockets. They also harass women on the street. It is during one of these dubious ventures that one of them snatched a hand bag from a woman and he was burnt to death. Through this action, the author by implication is against extra-judicial killing. Although the victim is guilty of the crime, the law should be allowed to take it cause. They should be given a fair trial. This is because some victims at times are innocent but before they could prove their innonce, the angry mob would have killed them.

Maude's attitude towards stealing and defrauding people brings him into close contact with Maria Oduma. $\mathrm{He}$ and his gang steal in a bar where Maria operates as a bar girl, this leads to her being sacked. Maude later hears from Maria, of the heart-touching story of her former boyfriend Bozo Macika. Bozo's degenerated life style is traceable to poverty. Bozo's miserable life starts from his family rejection and sectionalism by his parents. This rejection results in Bozo taking to hooliganism as a means of survival. 
From the portrayal of the suffering, hardship, agony, and anguish the masses go through in the society, the author shows his empathy for this group of people, who are left to rot without any assistance from the government. The author shows his sympathy because the writer needs to commit himself to the problems of the society. Normally, a writer always identifies with the poor people in the society. This is why D. I. Nwoga (1978), quoting Jean Paul Sartre, said:

Like morality, literature needs to be universal. So that the writer must put himself on the side of the majority of the two billion starving, if he wishes to be able to speak to all and be read by all. Failing that he is at the service of a privileged class and, like it, an exploiter. (pp. 3-4).

Bozo's father calls him "son of a bitch" because he was given birth to through caesarian operation and his mother was advised not to give birth again. As a result of the circumstances surrounding Bozo's birth, his father hates him and declares publicly that, at his death, Moyo, his daughter, will inherit his property. This is why the author says: "This young lady Abe would announce to friends...this beautiful young lady to be precise-this extremely beautiful Mae West, is my heiress. If I kick the bucket today, she gets everything that belongs to me" (p. 32).

Bozo is hated by his father Mr. Abednego because he makes him to become impotent and his father always wished he had died at the hospital years ago. Mr. Abednego pays more attention to the needs and aspirations of Moyo especially Moyo's education and none for Bozo. Bozo therefore feels hated and cheated when he discovers that his father loves Moyo more than him. Bozo becomes more aggrieved when he learns that his father hates him because of the circumstances surrounding his birth, which he is not the cause. Hence, Bozo says:

So he does hate me, Bozo thought bitterly. So he hates me so much I made him impotent. Me, make somebody, impotent? That's crazy; I didn't have a magic wand! I didn't make anybody impotent. All I know is somebody's impotent and he can't reconcile himself with reality and he's making me the scapegoat. He's blaming me for something that happened before I was born. And now he wants to kill me. Now he wants me dead. Oh, God, wherever you are, I am tired of being a fall-guy. (p. 35)

It is this manifest hatred by Mr. Abednego that leads to the disintegration and annihilation of his family.

Bozo was a dedicated and avowed catholic. However, after reading books on philosophy, theology, and metaphysics, he started to question the nature of Christ and the entire Christian faith. Later, he stops going to the church and begins to rejects the dogmas of the church. Bozo is expelled from the school because he questions the authenticity of the Christian religion which Mrs. Buck teaches. Bozo makes nonsense of the Christian religion which Mrs. Buck impacts on them. His strange belief that Christianity is inauthentic religion makes Mrs. Buck to collapse and Bozo is expelled because of this.

Bozo's family is in tumult as a result of the incestuous act of his father with Moyo his daughter. This cumulates in Moyo's pregnancy. Mrs. Abednego, not able to bear the horrible and sacrilegious act between her husband and her daughter, decides to kill the two of them. Mrs. Abednego laments and says:

At that moment I temporally lost my sanity. I felt fury drench my skin like a bucket of ice-cold water. I felt like a vampire, I wanted to taste blood, to feel the blood of the monster I married eighteen years ago.... I went into the kitchen and looked for a sharp object. Any sharp object would do. Finally, my eyes fell on that knife we bought last Christmas to slaughter the goats. I stabled him stabbed him and couldn't stop stabbing him. (pp. 60-61)

The action of Mrs. Abednego is a replica of that of Zifa in J. P. Clark's (1985) Song of a Goat when Zifa 
discovers that his younger brother Tonye had sexual intercourse with his wife Ebiere as a result Zifa's impotency. Zifa drives Tonye to commit suicide and Zifa himself commits suicide. The action of Mrs. Abednego shows that a man cannot be the husband of his wife and daughter at the same time. It is a taboo, a heinous crime, and abominable act. Mrs. Abednego realizes this and this realization leads to her murdering of her husband and daughter.

In a bid to seek for safe haven, because of the calamity that has bedeviled Bozo's family, he goes to Mitchell Socrates who introduces him to marijuana. This marijuana further aggravates the problems of Bozo. It makes him to be more debased and a social deviant. The uncaring and inhuman way the society treats its citizens are vividly manifested in the person of Maria Odum who has been exploited, abused, and discarded by the society. She lives a frustrated and miserable life until she meets Mitchell Socrates. According to the authorial voice:

She had lived all her life in an exploitative, soul-debilitating society which not only seemed not to want her, but also ambivalently gripped her with the hug of a lion. Maria had been a persistently unlucky person until Mitchell Socrates came into her life. She had lived in the midst of violence and misery all her life. (p. 80)

Maria's father, a pauper dies. He had 14 children. None of the children was educated because education was not for the poor in the society. Despite his debased nature, he was always forced to pay taxes. Two of Maria's brothers were forced to run into the river never to be seen again because of tax evasion. Their father dies of tuberculosis and Maria's two brothers were killed while trying to smuggle their father into a hospital mortuary since they could not pay for his burial in the local government cemetery. As a result of the numerous and frustrating problems ravaging Maria's family, she decides to commit suicide in a river. However, she was saved by Socrates who also wants to commit suicide but decides otherwise on seeing Maria. Maria was now taken home by Socrates and they become companions. Maria becomes Bozo's lover.

Bozo, apart from being a drug addict, becomes frustrated and disillusioned. He is sad and not happy with the society because of the suffering of the plebeians, the high rate of corruption, and the nonchalant attitude of government to the plight of the downtrodden. The miserable life of Mitchell Socrates, Bozo, and Maria is similar to that of Kofi Billy, Maanan, and the Teacher in Ayi Kwei Armah's (1969) The Beautiful Ones Are not Yet Born. As a result of the fact that the corruption in the society was too much for Kofi Billy to bear, he commits suicide. Maanan, on her part, takes to smoking marijuana in an attempt to run away from the corruption in the society and the teacher goes into a life of loneliness, a sort of death.

We can see that, in order to cope with the frustration and corruption in the society, some people become drug addicts, hooligans, and gangsters and, at the extreme, commit suicide. From the above, Biyi Bandele-Thomas (1996), by implication, was saying that the quality of life lived by the people depends on the quality of government in place in any society.

The author uses the novel to lampoon the way innocent little boys are used for selfish purposes in the society. These innocent little boys are indoctrinated by Muslim religious teachers. They are used to commit violent crimes and inflict harms on the people. According to the author:

Sometimes unscrupulous people in our society take undue advantage of these boys and exploit them for their basic ends. An example is Muhammadu Marwa, almajairai better known as Maitatsine, who, under the guise of religious motivation used almajairai in the rank of his soldiery during his so-called jihad in Kano in $81 \ldots$. He'd picked a poor, hungry almajairai from off the streets offer him permanent shelter and personal satisfaction and ask him to join his fold. (p. 105) 
The boys that are indoctrinated, called almajairai, are made to fight and kill those who do not share their beliefs. The author, through effective characterization and the use of appropriate diction, has been able to convey his message through to the people. Characters like Maude Bose, his mother, Bozo, Marie Oduma, and the indoctrinated little boys represent the downtrodden in the society that are exploited, abused, and abandoned by members of the ruling class.

The politicians and religious teachers represent the ruling class that exploit, abuse, and indoctrinate poor people and paupers who have no means of survival. So, they are easily manipulated to meet the whims and caprices of their masters.

The author uses words, like "air...fouled" and "vile-smalling" to express his disgust over the rail transportation in Nigeria. The author also uses words, like "grisly smell of death" (p. 81), "dying of tuberculosis" (p. 81), "flush-lavatories" (p. 83), "bucket latrines" (p. 83), and "night-soiled man" (p. 83) to portray the hazards and dirty experiences faced by Maria's family.

\section{Conclusion}

The author of the Man Who Came From the Back of Beyond, Biyi Bandele Thomas, has successfully played his role as the conscience of the society in this novel by documenting the social, political, and economic woes ravaging the society. His work creates the awareness the people need to change their perception of the society and wake up from their slumber.

The author uses the novel to mirror the social, political, moral, and economic decay in the society. It also pictures the horrible conditions the masses are subjected to by the ruling class and the use of religion to enslave and make the people prisoners of conscience. The people, in an attempt to find succor in the midst of all the quagmires, resort to all forms of social vices such as armed robbery, prostitution, hooliganism, drug addiction, and religious fanaticism. All these problems are caused by the uncaring nature of our leaders. So, what the author is saying in this novel is that our leaders are responsible for all the decays in the society. If there must be a decent society, the leaders must themselves be decent, caring, have human feelings, and be filled with the milk of human kindness. If these qualities are present in our leaders, the people and the society will experience heaven on earth. Their promises to the people will not amount to a mere Communist Utopia or false Eldorado.

\section{References}

Armah, A. (1969). The beautiful ones are not yet born. London: Heinemann.

Awosika, O. (1997). Form and technique in the African novel. Ibadan: Sam Bookman Educational Communication Services.

Bandele-Thomas, B. (1996). The man who came from the back of beyond. Ibadan: Spectrum Books Limited.

Clark, J. P. (1985). Song of a goat in three plays. Oxford: Oxford University Press.

Nwoga, D. I. (1978). Literature and modern West African culture. Benin City: Ethiope Publishing Cooperation.

Omoregbe, J. (1989). Ethics: A systematic and historical study. Ikeja: JoJa Press Limited.

Omoregbe, J. (2006). Philosophy of mind: An introduction to philosophical psychology. Ikoja: Joja Press Limited.

Palmer, E. (1982). Growth of the African novel. London: Heinemann.

Thiongo's, N. W. (1977). Petals of blood. London: Heinemann. 